\title{
SMALL NOTE ON THE COMPOSTION OF BRAZILIAN MANTLE
}

\section{IGOR VICTOROVICH ASHCHEPKOV ${ }^{1}$, VALENTIN PETROVICH AFANASIEV ${ }^{1}$, NIKOLAI PETROVICH POKHILENKO $^{1}$, NIKOLAI VLADIMIOROVICH SOBOLEV ${ }^{1}$, NIKOLAI VASILIEVICH VLADYKIN ${ }^{2}$, ANATOLYI ILYICH SAPRYKIN ${ }^{1}$, OLGA STEPANOVNA KHMEL'NIKOVA ${ }^{1} \&$ GENADYI NIKITOVICH ANOSHIN $^{1}$}

\begin{abstract}
Garnets from concentrate from the Vargem I kimberlite pipe show a long compositional range and reveal long linear trends within the lherzolite field in a $\mathrm{Cr}_{2} \mathrm{O}_{3}-\mathrm{CaO} \%$ diagram (Sobolev et al. 1974) (up to $11 \% \mathrm{MgO}$ ), formed by grains of different dimensions with few deviations to harzburgites. Larger grains (fraction +3 ) are higher in $\mathrm{CaO}$ with less $\mathrm{Cr}_{2} \mathrm{O}_{3}$ (to $5.5 \%$ ). $\mathrm{The} \mathrm{Cr}_{2} \mathrm{O}_{3}$ frequency reduces in hyperbolic function for each fraction. Ilmenites reveal $42-56 \% \mathrm{TiO}_{2}$ compositional range with linear $\mathrm{FeO}_{2}-\mathrm{MgO}$ correlations but $3(4)$ separate groups for $\mathrm{Al}_{2} \mathrm{O}_{3}$ suggest different proportion of co-precipitated garnet, probably due to polybaric fractionation. Increasing $\mathrm{Cr}_{2} \mathrm{O}_{3}$ and $\mathrm{FeO} \%$ content (fractionation degree) with reducing $\mathrm{TiO}_{2}$ is in accord with AFC model.

Garnet xenolith from Idaia II pipe with large Gar- Cpx grains and fine Mica-Carb bearing matrix refer to $60 \mathrm{kbar}$ and $35 \mathrm{mv} / \mathrm{m} 2 \mathrm{geotherm}$. It displays enriched trace element patterns but not completely equilibrated compositions for Gar and Cpx, suggesting low degree melting of relatively fertile mantle. Studied material may suggest metasomatized, relatively fertile and irregularly heated mantle beneath Southern Brazil as found by (CarvaIho \& Leonardos 1997).
\end{abstract}

Keywords: kimberlites, concentrate, garnet, ilmenites, trace elements, PT conditions, Brazil.

INTRODUCTION The composition of Brazilian mantle which is very preliminary studied (Meyer et al. 1991, CarvaIho \& Leonardos 1997, etc.) is of great interest, to compare with other Gondwana blocks that are usually productive in diamonds. Pyropes and garnets from a concentrate from the Vargem I kimberlite pipe (S. Inácio river valley) and a small xenolith and separated xenocryst from the Indaiá II kimberlite pipe were analyzed by EPMA and minerals in phlogopitebearing garnet lherzolite from Indaiá II by LAM ICP MS, in the analytical center of UIGGM SD RASc.

RESULTS Pyropes from the Vargem I kimberlite pipe, collected and analyzed by Afanasiev V.P., Pokhilenko N.P, and Sobolev N.V., reveal a linear trend within the lherzolitic field in $\mathrm{Cr}_{2} \mathrm{O}_{3}-\mathrm{CaO}$ diagrams (Sobolev 1977) ranging from 1 to $5 \%$ $\mathrm{Cr}_{2} \mathrm{O}_{3}$ in the fraction +3 , while the fraction $+0.25-0.5$ is more representative and contains more chromium-rich garnets, up to $10 \%$ as reported by Meyer et al. (1991). Larger garnet grains are less rich in chromium but have slightly higher $\mathrm{CaO}$. The $\mathrm{Fe}$ and $\mathrm{Ti}$ contents gently decrease with increasing $\mathrm{Cr}_{2} \mathrm{O}_{3}$ (Fig. 1)(Table.1). Frequency histogram for $\mathrm{Cr}$ displays several peaks and generally rapidly falls especially for larger grain sizes. Pyropes often display negative forms after the intergrowths with the phlogopites.

Ilmenites show the common trend of decreasing $\mathrm{MgO}$, $\mathrm{Al}_{2} \mathrm{O}_{3}, \mathrm{NiO}$ with the increase in $\mathrm{Cr}_{2} \mathrm{O}_{3}, \mathrm{FeO}, \mathrm{V}_{2} \mathrm{O}_{3}$ (Moor et al 1991, Griffin et al. 1997) (Fig.2. Table 1) though some elements reveal considerable scattering across the main trend. This is likely the result from the crystallization and interaction with the peridotitic mantle. The reducing of frequency for low $-\mathrm{MgO}$ varieties suggests fractional crystallization (Moore et al. 1991, Griffin et al. 1997). However the increase in $\mathrm{Cr}_{2} \mathrm{O}_{3}$ content shows that if this is the case ilmenite (KD with melt $3-$ 6) was not the main precipitation phase but crystallized in the silicate assemblage at least in the initial stage. $\mathrm{Al}_{2} \mathrm{O}_{3}$ clustering in three groups suggests the different proportion of coeval garnet crystallization. The AFC (De Paolo 1981) may be also suggested to explain $\mathrm{Cr}_{2} \mathrm{O}_{3}$ increase and $\mathrm{Ni}$ scattering, while essential ilmenite precipitation produces the decreasing $\mathrm{Cr}_{2} \mathrm{O}_{3}$ sub trends visible in middle interval of the trend. The histograms for separate elements do not coincide. Some grouping of the points is possibly explained by the separate capturing intervals of the rising magma or/and polybaric ilmenite fractionation from the same early portion of rising of kimberlite magma in pre-eruption stage.

$\mathrm{Cr}$-spinels display a range from 59 to $30 \% \mathrm{Cr}_{2} \mathrm{O}_{3}$. As for garnet, the frequency also reduces for the more $\mathrm{Cr}$ - rich spinel varieties.

Garnet lherzolite xenolith from INDAIÁ II is a partly serpentinized nodule $2 \times 1.5 \times 2 \mathrm{~cm}$ with large rounded garnet and smaller clinopyroxene grains with minor orthopyroxene (mostly altered) and phlogopite. (Table. 2) The rock seems to be partly recrystallized and has porhyroclastic structure. The carbonate grains were determined in fine grained aggregate.

MAJOR AND TRACE ELEMENTS The trace-element composition of the minerals (garnet and pyroxenes) is close to that of such minerals for South Africa (van Achterbergergh et al. 1998). They possibly were not in complete equilibrium judging by the KD-reconstructed trace element distributions (Table.3) (Fig.3). Trace elements suggest lower degree of melting for the clinopyroxenes then for garnets and slightly different melting associations. The melting assemblage for clinopyroxene possibly includes some amount of metasomatic minerals including phlogopite (elevated $\mathrm{Ba}, \mathrm{Sr}$ ). High $\mathrm{Nb}, \mathrm{Ta}$, $\mathrm{U}$, Th concentrations suggest melting of a nearly primitive source. Comparing with the minerals from Aldan craton keel these are more enriched in incompatible elements suggesting 
a lower melting degree of more hydrous and fertile mantle peridotites.

THERMOBAROMETRY Calculated TP conditions for the described xenolith plots on the $35 \mathrm{mv} / \mathrm{m}^{2}$ geotherm as reported by Carvalho \& Leonardos (1997). Clinopyroxene thermobarometry (Nimis and Taylor, 2000), (Ashchepkov 2001) for pyroxene xenocrysts found in the kimberlite matrix reveals more scattering but also yields values in 50-65 kbar interval (Fig.4). It should be noted that in the examined xenolith the $\mathrm{Cr}_{2} \mathrm{O}_{3}$ content of garnet $(5 \%)$ is close to the maximal values for grains in fraction +3 in the concentrate. Thus at pressure 60-65 kbar the garnets may still be relatively low in $\mathrm{Cr}$, which is explained by a fertile mantle composition.
CONCLUSION Judging from the studied mineral concentrate and xenolith the mantle keel beneath $\mathrm{S}$. Brazil is layered as proved by Carvalho \& Leonardos (1997). The megacrystalline ilmenite nodules display long probably polybaric fractionation trend according to $\mathrm{AFC}$ model at least in final stages. The abundant phlogopite metasomatism probably results from the ancient processes of continental collision.

Acknowledgements Work supported by RFBR grants, 9905-65688, 00-05-65288. To two anonymous referees of RBG for suggestions to the manuscript.

\section{References}

Ashchepkov I.V. 2001. Jd barometer for mantle peridotites and eclogites and thermal conditions of the lithospheric keels of cratons and their surroundings. GSA November 5 - 8, 2001 Annual Meeting.

Brey G.P. \& Kohler T. 1990. Geothermobarometry in four phase lherzolites II: new thermobarometers and practical assessment of using thermobarometers. J. Petrol., 31:1353-1378.

Carlson R. W., Esperança S., Svisero D. P. 1996. Chemical and Os isotopic study of Cretaceous potassic rocks from Southern Brazil. Contrib. Mineral. Petrol., 125:393-405

Carvalho J.B. \& Leonardos O.H. 1997. Garnet peridotites from the Três Ranchos IV kimberlitic pipe, Alto Paranaíba igneous province, Brazil: geothermobarometric constraints. Russian Geol. Geophys., 38(1):159-172.

DePaolo D. 1981. Trace elements and isotopic effects of combined wall-rock assimilation and fractional crystallization. Earth. Plan. Sci. Lett., 53:198202.

Griffin W.L., Moore R.O., Ryan C.G., Gurney J.J., and Win T.T. Geochemistry of magnesian ilmenite megacrysts from Southern African kimberlites. Russian Geol. Geophys. 38/2: 398-419.
MacGregor, I.D. 1974. The system $\mathrm{MgO}-\mathrm{Al}_{2} \mathrm{O}_{3}-\mathrm{SiO}_{2}$ : solubility of $\mathrm{Al}_{2} \mathrm{O}_{3}$ in enstatite for spinel and garnet-spinel compositions. Am. Mineral., 59:11019.

Moor R.O., Griffin W.L., Gurney et al. 1992. Trace element geochemistry of ilmenites megacrysts from the Monastery kimberlite, South Africa, Lithos, 29:1-18.

Nimis P. \& Taylor W. 2000. Single clinopyroxene thermobarometry for garnet peridotites. Part I. Calibration and testing of a $\mathrm{Cr}$-in-Cpx barometer and an enstatite-in-Cpx thermometer. Contrib Mineral Petrol 139 /5: 541-554.

Sobolev N.V.1977. Deep seated inclusions in kimberlites and the problem of the composition of the upper mantle AGU. 279 p.

Van Achterbergergh E., Griffin W.L., Shee S.R., Wyatt B.A., Sharma A.L. 1998. Natural trace element distribution coefficients for garnet clino- and orthopyroxene: variations with temperature and pressure. 7th International Kimberlite Conference. Extended abstracts. Capetown. Pp.934-936.

Manuscrito NB-35 Recebido em 18 de novembro de 2001 Revisão dos autores $\mathrm{em} 22$ de dezembro de 2001 Revisão aceita em 23 de dezembro de 2001 
12

\section{w $\mathrm{t} \%$}

10
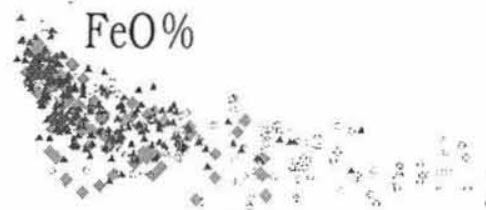

$\mathrm{CaO} \%$

6

4

Fraction +3

- Fraction $+1 \cdot 3$

- Fraction + 0.5-1

2

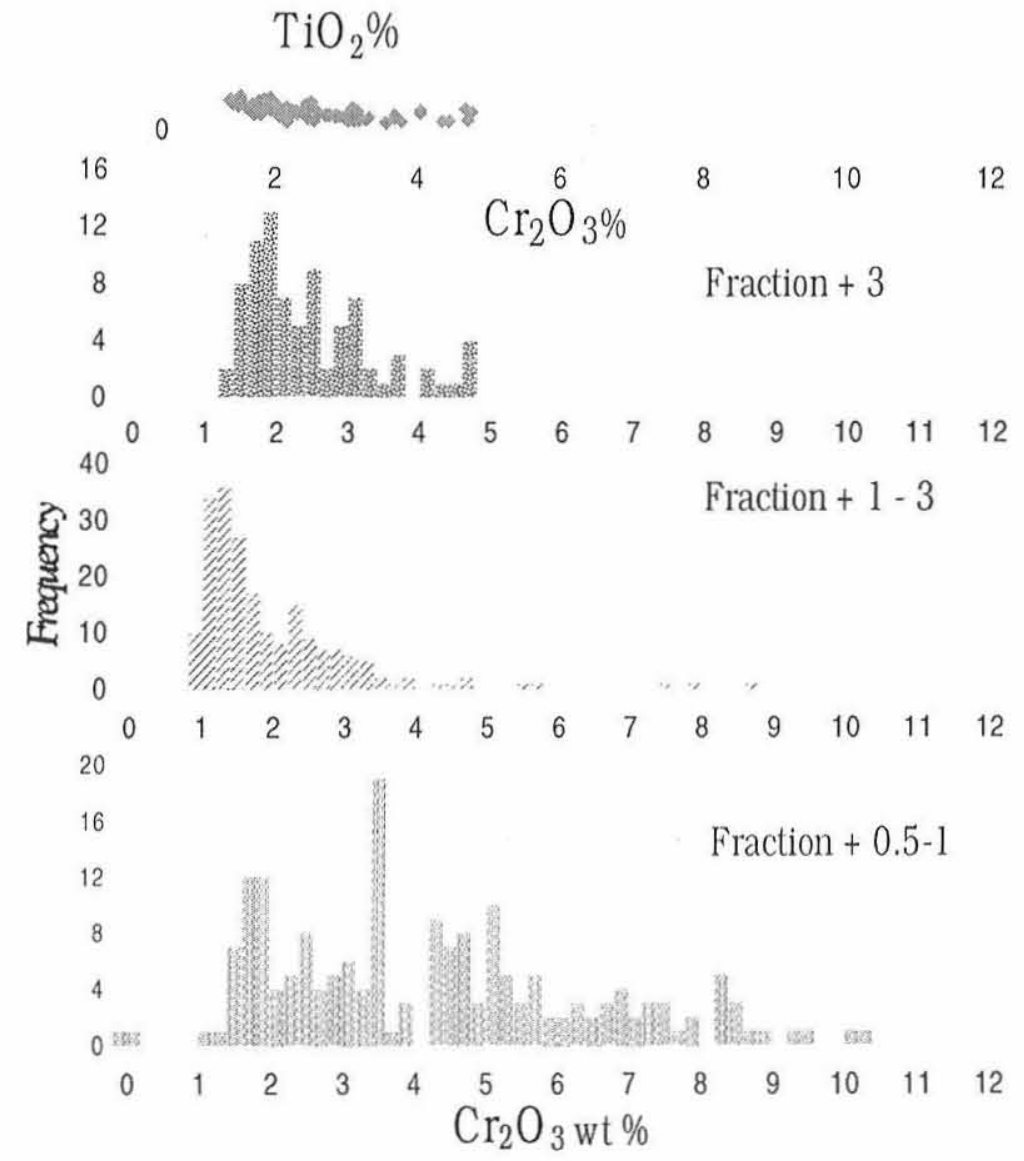

Figure I - Garnet compositions in different fractions from concentrate of kimberlite Vargem I, Santo Inácio River valley and their frequency histograms. Data for the garnets are collected and analyzed by Afanasiev V.P, Pokhilenko N.P., Sobolev N.V. during the field trip of the 5 th $I K C$. 
Table I - Composition of the selected minerals from the concentrate from the Vargem I intrusion, Santo Inácio River valley

\begin{tabular}{|c|rrrrrrrrr|r|}
\hline Oxide & \multicolumn{1}{|c|}{ Garnets } \\
\hline $\mathrm{SiO} 2$ & 41.35 & 41.38 & 40.92 & 41.59 & 40.12 & 39.54 & 40.78 & 40.15 & 40.12 & 40.2 \\
$\mathrm{TiO} 2$ & 0.11 & 0.12 & 0.35 & 0.35 & 0.09 & 0.12 & 0.1 & 0.085 & 0.08 & 0.7 \\
$\mathrm{Al} 2 \mathrm{O} 3$ & 19.97 & 20.34 & 21.10 & 21.62 & 18.40 & 19.01 & 17.99 & 17.14 & 16.97 & 17.10 \\
$\mathrm{Cr} 2 \mathrm{O} 3$ & 4.56 & 3.26 & 2.55 & 1.56 & 7.44 & 8.54 & 8.99 & 9.45 & 10.16 & 10.26 \\
$\mathrm{FeO}$ & 9.36 & 8.70 & 9.68 & 9.99 & 9.13 & 8.31 & 8.33 & 8.49 & 8.01 & 8.29 \\
$\mathrm{MnO}$ & 0.46 & 0.45 & 0.47 & 0.43 & 0.44 & 0.43 & 0.42 & 0.46 & 0.42 & 0.4 \\
$\mathrm{MgO}$ & 19.52 & 19.52 & 19.80 & 19.86 & 19.84 & 17.85 & 16.97 & 17.02 & 18.68 & 16.72 \\
$\mathrm{CaO}$ & 5.59 & 5.14 & 4.63 & 4.41 & 4.83 & 6.61 & 7.01 & 6.72 & 5.23 & 7.42 \\
\hline $\mathrm{Total}$ & 100.91 & 100.91 & 100.91 & 100.91 & 100.29 & 100.41 & 100.59 & 99.52 & 99.67 & 101.09 \\
$\mathrm{Fe} /(\mathrm{Fe}+\mathrm{Mg}) \%$ & 21.21 & 20.01 & 21.53 & 22.02 & 20.52 & 20.71 & 21.60 & 21.87 & 19.40 & 21.77 \\
\hline
\end{tabular}

\begin{tabular}{|c|c|c|c|c|c|c|c|c|c|}
\hline Oxide & Ilmenites & & & & & & & & \\
\hline $\mathrm{TiO} 2$ & 50.95 & 52.01 & 50.02 & 52.72 & 48.72 & 47.32 & 44.31 & 45.17 & 53.07 \\
\hline $\mathrm{Al} 2 \mathrm{O} 3$ & 0.45 & 0.46 & 0.51 & 0.20 & 0.13 & 0.04 & 0.04 & 0.008 & 3.68 \\
\hline $\mathrm{Cr} 2 \mathrm{O} 3$ & 4.43 & 3.40 & 3.03 & 0.89 & 1.58 & 1.15 & 2.90 & 2.65 & 0.607 \\
\hline $\mathrm{FeO}$ & 31.55 & 31.00 & 35.63 & 36.07 & 39.58 & 44.57 & 44.74 & 44.73 & 33.33 \\
\hline $\mathrm{MnO}$ & 0.32 & 0.41 & 0.38 & 0.36 & 0.43 & 0.33 & 0.40 & 0.408 & 0.296 \\
\hline $\mathrm{MgO}$ & 12.18 & 11.85 & 9.80 & 9.78 & 8.89 & 6.44 & 5.99 & 5.98 & 9.6 \\
\hline $\mathrm{NiO}$ & 0.13 & 0.26 & 0.14 & 0.18 & 0.22 & 0.12 & 0.12 & 0.061 & 0.162 \\
\hline V2O5 & 0.37 & 0.29 & 0.32 & 0.18 & 0.44 & 0.44 & 0.45 & 0.327 & 0.402 \\
\hline Total & 100.37 & 99.67 & 99.83 & 100.39 & 99.98 & 100.41 & 98.94 & 99.334 & 101.147 \\
\hline
\end{tabular}

Table 2 - Composition of minerals from the garnet- Iherzolite xenolith, Indaiá II pipe

\begin{tabular}{|c|c|c|c|c|c|c|}
\hline Oxides & Cr-Diopside & Enstatite & Garnets & Olivine & Phlogopite & Carbonatite \\
\hline $\mathrm{SiO} 2$ & 54.82 & 57.90 & 41.50 & 40.79 & 40.74 & 0.00 \\
\hline $\mathrm{TiO} 2$ & 0.10 & 0.02 & 0.16 & 0.00 & 0.87 & 0.00 \\
\hline $\mathrm{Al} 2 \mathrm{O} 3$ & 1.64 & 0.23 & 19.94 & 0.04 & 13.15 & 0.07 \\
\hline $\mathrm{Cr} 2 \mathrm{O} 3$ & 1.71 & 0.15 & 5.11 & 0.03 & 0.74 & 0.00 \\
\hline $\mathrm{FeO}$ & 2.55 & 4.65 & 8.02 & 7.98 & 4.09 & 1.02 \\
\hline $\mathrm{MnO}$ & 0.09 & 0.11 & 0.44 & 0.09 & 0.02 & 0.69 \\
\hline $\mathrm{MgO}$ & 17.10 & 35.94 & 19.17 & 50.08 & 25.55 & 3.58 \\
\hline $\mathrm{CaO}$ & 18.93 & 0.38 & 5.09 & 0.14 & 0.02 & 54.07 \\
\hline $\mathrm{Na} 2 \mathrm{O}$ & 1.83 & 0.13 & 0.03 & 0.20 & 0.16 & 0.00 \\
\hline $\mathrm{K} 2 \mathrm{O}$ & 0.07 & 0.01 & 0.01 & 0.10 & 11.58 & 0.01 \\
\hline $\mathrm{NiO}$ & 0.057 & 0.117 & 0.018 & 0.359 & & 0.104 \\
\hline Total & 98.85 & 99.52 & 99.46 & 99.44 & 96.92 & 59.44 \\
\hline $\mathrm{Fe} /(\mathrm{Fe}+\mathrm{Mg}) \%$ & 7.72 & 6.77 & 19.01 & 8.21 & 8.24 & 13.78 \\
\hline
\end{tabular}


Igor Victorovich Ashchepkov et al.
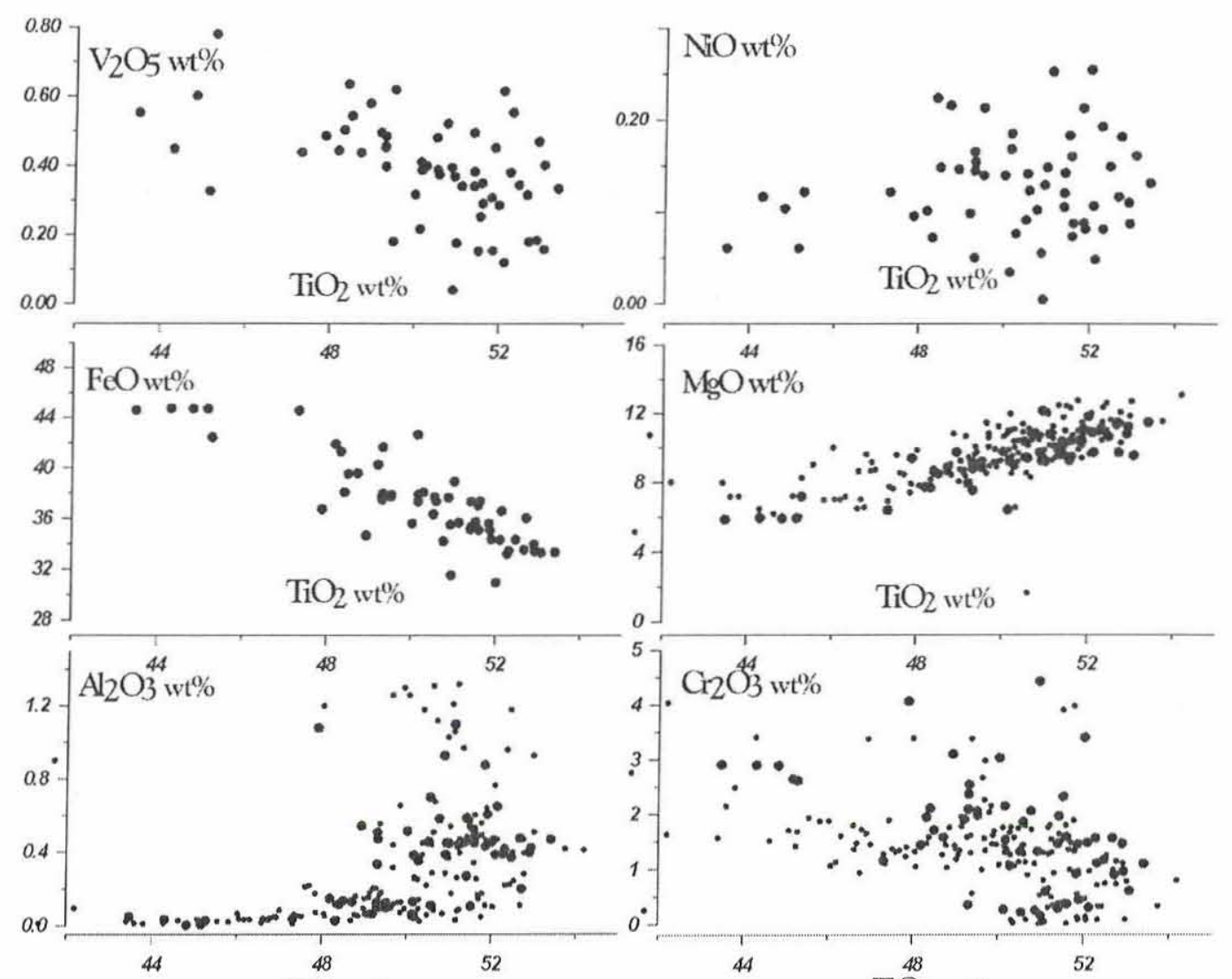

$\mathrm{TiO}_{2} w \mathrm{w} \%$
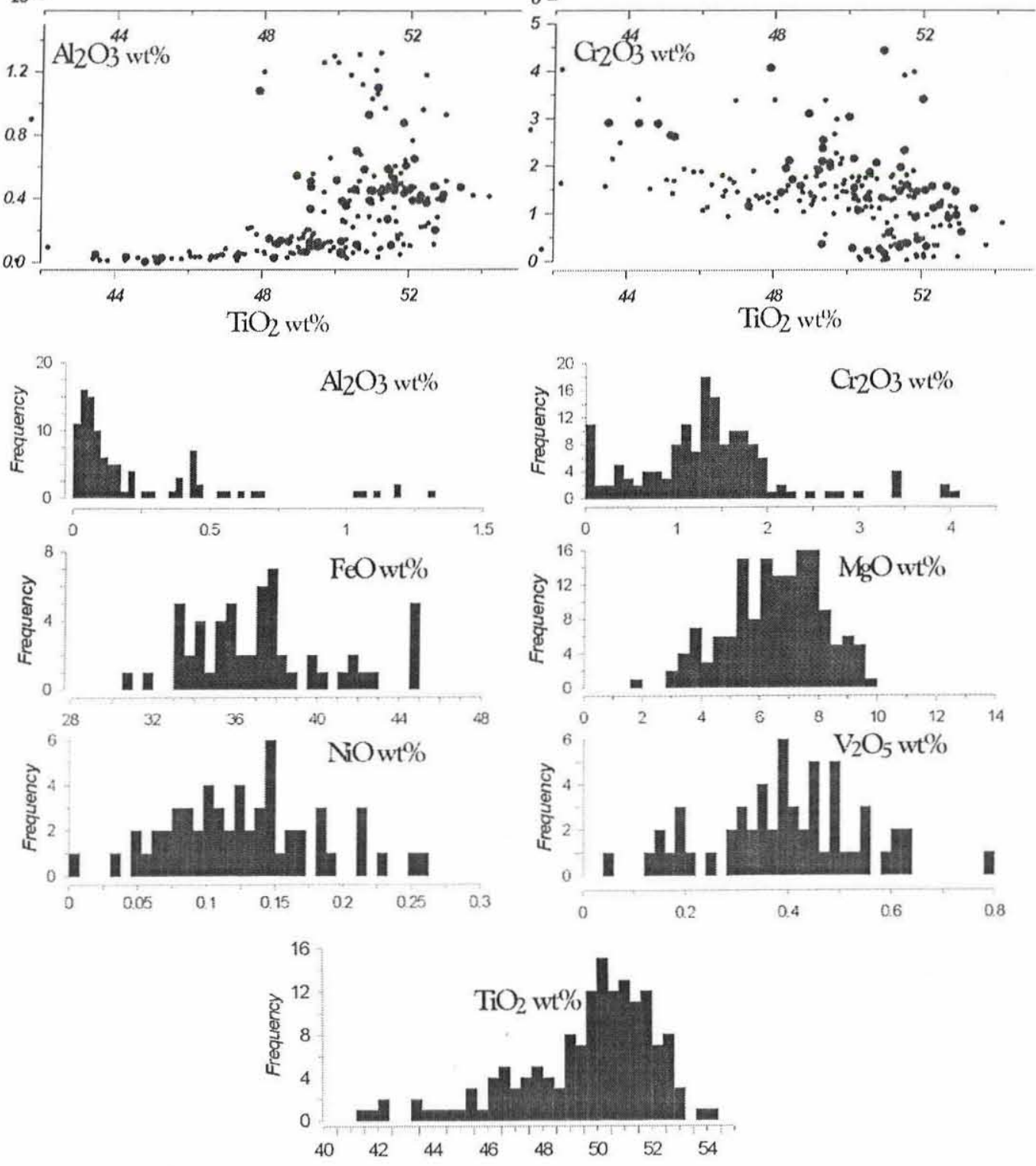

Figure 2 - Variation diagram for the ilmenites from the same Vargem II kimberlite. Small dots are the partial analyses of small grains made by Afanasiev V.P. Pokhilenko N.P., Sobolev N.V. Large dots analyses of fraction +3 ilmenite nodules, made by Ashchepkov I.V.. 
Table 3 - Compositions of the major and trace elements in minerals from garnet- lherzolite xenolith, Indaiá pipe.

\begin{tabular}{|c|c|c|}
\hline $\begin{array}{l}\text { N Sample } \\
\text { Component }\end{array}$ & In I Cpx & InI-Gar \\
\hline $\mathrm{SiO}_{2}$ & 54.82 & 41.50 \\
\hline $\mathrm{TiO}_{2}$ & 0.10 & 0.16 \\
\hline $\mathrm{Al}_{2} \mathrm{O}_{3}$ & 1.64 & 19.94 \\
\hline $\mathrm{Cr}_{2} \mathrm{O}_{3}$ & 1.71 & 5.11 \\
\hline $\mathrm{FeO}$ & 2.55 & 8.02 \\
\hline $\mathrm{MnO}$ & 0.09 & 0.44 \\
\hline $\mathrm{MgO}$ & 17.10 & 19.17 \\
\hline $\mathrm{CaO}$ & 18.93 & 5.09 \\
\hline $\mathrm{Na}_{2} \mathrm{O}$ & 1.83 & 0.03 \\
\hline $\mathrm{K}_{2} \mathrm{O}$ & 0.074 & 0.007 \\
\hline $\mathrm{NiO}$ & 0.057 & 0.018 \\
\hline Total & 98.86 & 100.32 \\
\hline $\mathrm{mg}^{\prime}$ & 0.077 & 0.190 \\
\hline $\mathrm{Ba}$ & 38.68 & - \\
\hline La & 8.87 & 0.02 \\
\hline $\mathrm{Ce}$ & 29.34 & 0.14 \\
\hline $\operatorname{Pr}$ & 4.61 & 0.04 \\
\hline$N d$ & 17.66 & 0.35 \\
\hline Eu & 0.73 & 0.10 \\
\hline $\mathrm{Sm}$ & 3.12 & 0.21 \\
\hline Gd & 1.74 & 0.38 \\
\hline $\mathrm{Tb}$ & 0.19 & 0.08 \\
\hline Dy & 0.80 & 0.53 \\
\hline $\mathrm{Ho}_{\mathrm{O}}$ & 0.10 & 0.14 \\
\hline Er & 0.24 & 0.40 \\
\hline $\mathrm{Tm}$ & 0.03 & 0.06 \\
\hline $\mathrm{Yb}$ & 0.15 & 0.50 \\
\hline Lu & 0.02 & 0.09 \\
\hline $\mathrm{Hf}$ & 2.30 & 0.23 \\
\hline $\mathrm{Zr}$ & 79.84 & 9.28 \\
\hline$Y$ & 3.46 & 4.19 \\
\hline $\mathrm{Ta}$ & 0.06 & 0.01 \\
\hline $\mathrm{Nb}$ & 3.47 & 0.53 \\
\hline Th & 0.13 & 0.06 \\
\hline U & 0.17 & 0.04 \\
\hline $\mathrm{Sr}$ & 576.36 & 28.89 \\
\hline $\mathrm{Rb}$ & 2.28 & 1.75 \\
\hline $\mathrm{Cs}$ & 0.13 & 0.19 \\
\hline $\mathrm{Pb}$ & 1.90 & 2.57 \\
\hline $\mathrm{Co}_{0}$ & 52.08 & 43.21 \\
\hline $\mathrm{Cu}$ & 130.54 & 91.87 \\
\hline $\mathrm{Zn}$ & 9.69 & 4.75 \\
\hline $\mathrm{Au}$ & 0.01 & 0.02 \\
\hline
\end{tabular}

Note. The EMPA analyses were done in UIGGM SD RAS, Novosibirsk on ComebaxMicro, operator Khmelnikova O.S. Trace elements are done by LA-ICP MS on "Finigan Element" in analytic center of UIGGM SD RASC with the laser "UV LaserProbe", the operators - P.A.Gerasimov, A.I.Saprykin 


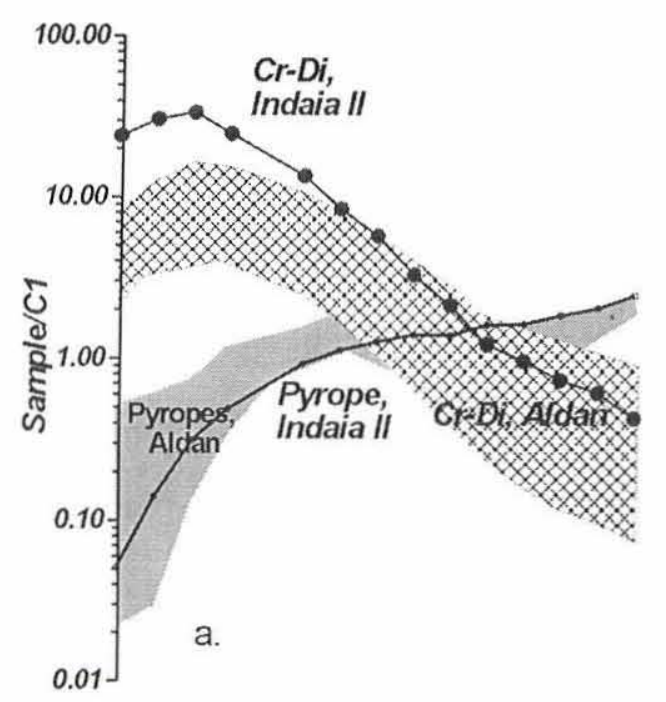

Trace element patternts for Pyrope and Cr-Diopside from Indaia II Gamet Iherzolite xenolith

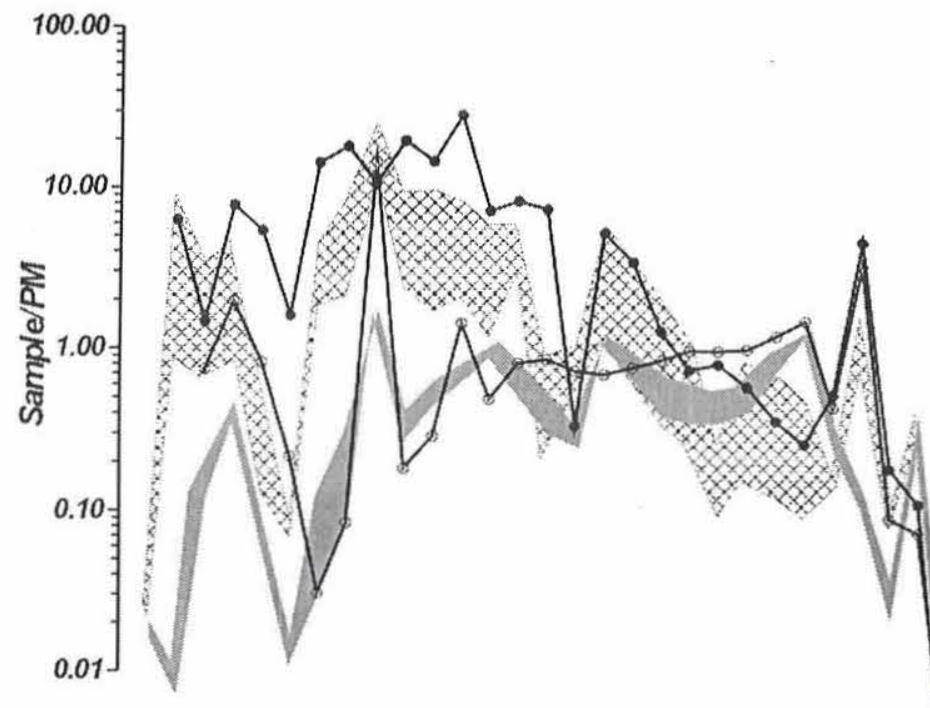

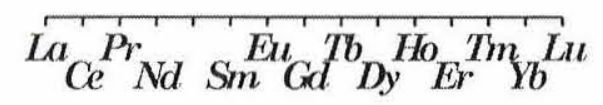

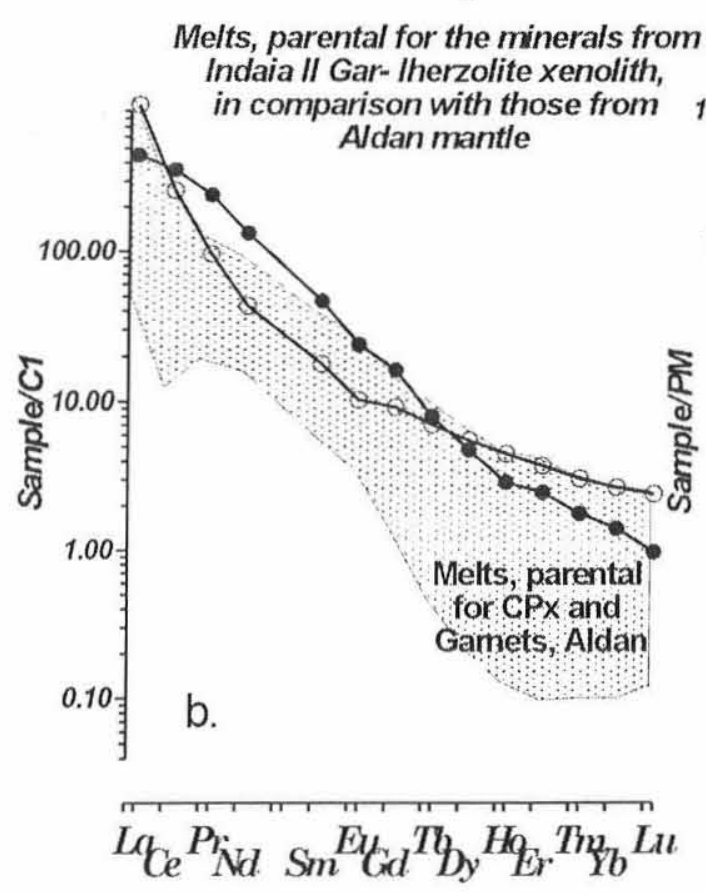

CS Ba U Ta Ce Pr Sr Hf Ti Gd Ho Er Lu Ca Bi Rb Th No La Pb Nd Sin Zr Eu Dy Y Yo Co Zn Au

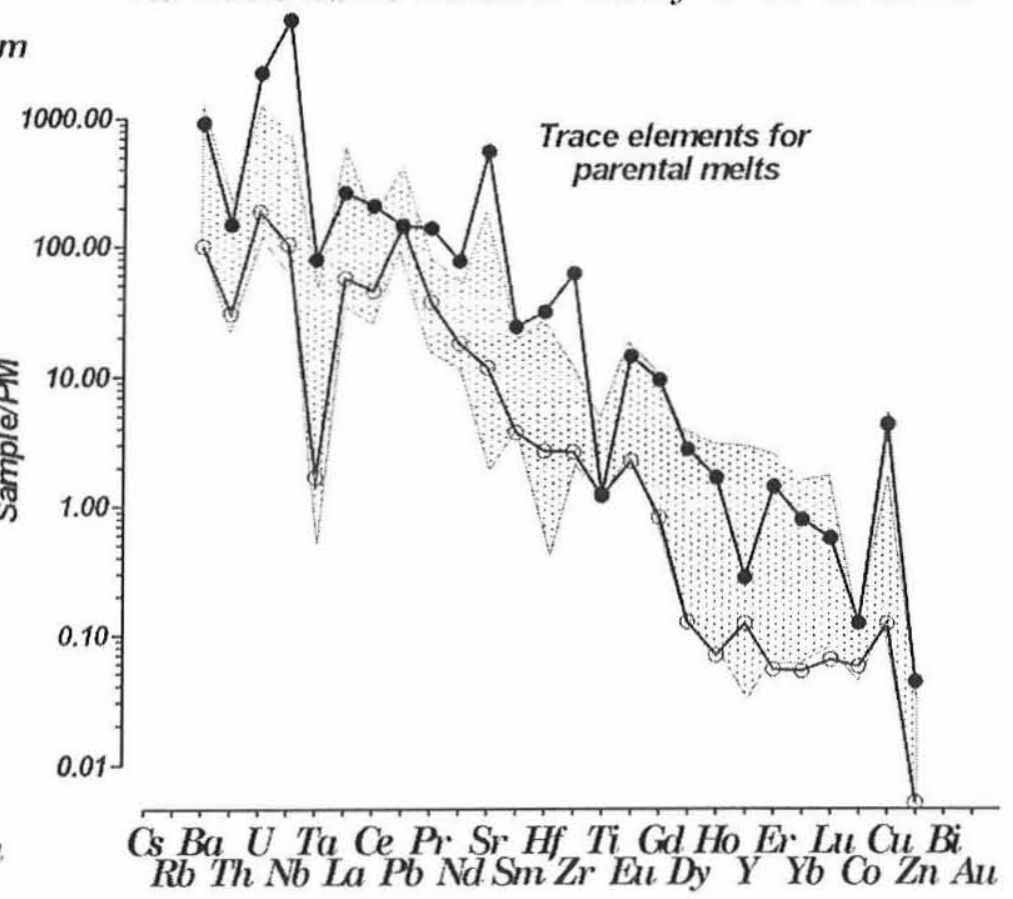

Figure 3 - Trace elements for the clinopyroxene and garnet from garnet lherzolite, Indaiá II pipe. 


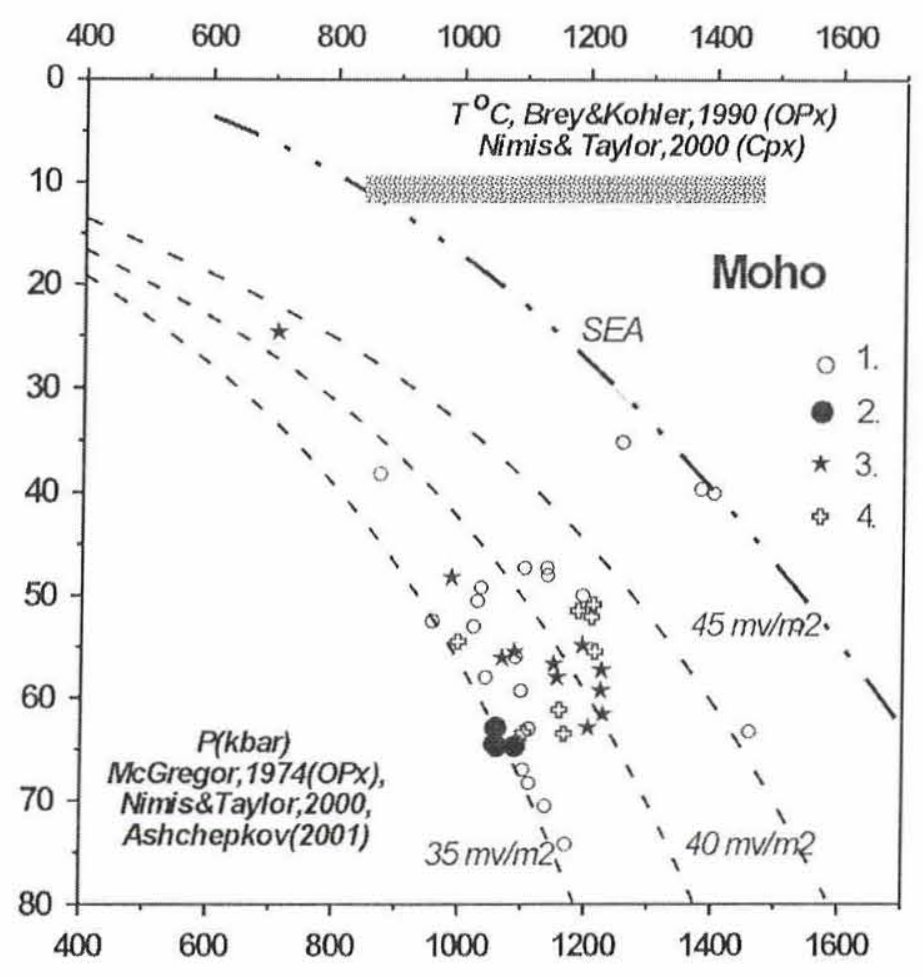

Figure 4 - PT plot for the xenoliths from Indaiá comparing with those from Três Ranchos IV pipe. 1. TP estimates for Três Ranchos IV (Carvalho \& Leonardos 1997). 2. TP estimates for the xenolith from Indaia II kimberlite pipe using Opx thermobarometry (Brey, Kohler 1990) - (McGregor 1973). 3. TP estimate for the Cr-Diopside xenocrysts from the kimberlite Indaiá II using (Nimis and Taylor, 2000) thermobarometry. 4. TP estimates on the Cr-Diopside xenocrysts from the kimberlite Indaiá II using (Nimis \& Taylor 2000) thermometer and (Ashchepkov 2001) barometer: 